\title{
Comparative Study of Efficacy of Cryosurgery and Albothyl Solution in the Management of Cervical Erosion in a Rural Hospital.
}

\author{
Dr. B. Shilpa Shivanna ${ }^{1}$, Dr. Lalitha Shivanna ${ }^{2}$, Dr. Prema Kulkarni ${ }^{3}$ \\ 1. Associate Professor, Department of OBG, Adichunchangiri Institute of Medical Sciences, Mandyadist \\ 2. Professor and Head, Department of OBG, Mandya Institute of Medical Sciences, MandyaDist \\ 3. Ex-Professor, Department of OBG, Adichunchangiri Institute of Medical Sciences, Mandyadist
}

\begin{abstract}
: prevention of carcinoma cervix is one of the most successful strategy of cancer control and prevention. In developing countries still carcinoma cervix is one of the most common cause of death, the incidence being 99/100000 in India.Hence the importance of screening and treatment of benign cervical lesions like cervical erosion , a common gynaecological finding which has inflammatory or neoplastic origin. In 2009 WHO updated the recommendation of cryosurgery in CIN and cervical erosion. AIMS AND OBJECTIVES: To compare the effect of cryosurgery and albothyl solution in cases of cervical erosion after ruling out CIN3 and malignancy by Pap smear. To study the efficacy and time taken for healing of the lesion and the number of applications required.MATERIAL AND METHODS :60 cases attending the gynaec OPD at Adichunchangiri institute of medical sciences, Bellur over a period of one year were included in this study. After exclusion of malignancy by Pap smear 30 cases were treated with cryo and 30 cases with albothyl solution.CONCLUSION :Cervical erosion which is one of the commonest gynaecological problem characterised by vaginal discharge, post coital bleeding, low backache can be maximally benefited by cryo as well as local appliction of albothyl solution . cryo has $90 \%$ success rate whereas albothyl solution scores over cryo in being cheap and accessible to patients.
\end{abstract}

Keywords: Cervical erosion, Carcinoma, Cryosurgery, Albothyl solution.

\section{Introduction:}

Cervical erosion / ectopy is histologically defined as the replacement of squamous epithelium of portiovaginalis by columnar epithelium beyond external os and ranges from $17-50 \%$. ${ }^{1}$ Studies have proved that there is an association between ectopy and chlamydial trachomatis, HPV and immmunodeficiencyvirus. ${ }^{2,3}$ There is also an association between ectopy and CIN as precancerous lesions often develop at squamocolumnar junction and is vulnerable to oncogenic effects of carcinogens and can be treated. ${ }^{4,5}$ ACOG recommends all females who have been sexually active or have reached 18yrs, an annual pap smear test and pelvic examination should be done.As the disease takes $10-20$ years to progress from preinvasive to invasive disease, preventive measures such as screening and treatment modalities should be adopted. ${ }^{6,7}$

The specificity of cytology is $98 \%$, sensitivity is $57 \%$, false negative rate is $49 \%$. This can be reduced by liquid based cytology. According to ACOG, screening begins at 21 yrsupto 68-70 yrs . It is done every 2 yrs till 30 yrs and later from 30yrs if 3 consecutive smears are negative combined with HPV testing .cytology is reported by Bethesda system and treated with either ablative procedure ( thermo/cryo) or excisional procedures (LEEP/CO2 laser cone /cold knife conisation). Presnt study was planned to evaluate cervical erosion after cervical cytologyand investigations of STD diseases. To evaluate the effect of cryosurgery (greek word icycold ${ }^{7}$ )andalbothyl solution on cervical erosion.

CRYOSURGERY :(Cryos in greek means cold). It is the application of cold to destroy abnormal or diseased tissue. It is minimally invasive, out-patient procedure.Advantages :Cost effective, Does not damage neighbouring healthy tissue, No proven adverse effect, High cure rate of $85 \%$. Disadvantages :No tissue specification for HPR evaluation, Cannot treat larger \& extensive lesions in endocervical canal which should be followed by colposcopy. ${ }^{8}$

ALBOTHYL SOLUTION:(Phenyl methyl aldehyde) Albothyl gel with policresulero 0.09 grams (as liquid $360 \mathrm{mg} / \mathrm{g}$ ) is a gel which has got a wide range of uses in surgery, dermatology, cervical erosion, cervicitis, vaginal infections ${ }^{9} \&$ for hemostasis also.PROPERTIES: It will accelerate the process of wound healing process when the necrotic tissue get detached, It restores the acidic $\mathrm{pH}$ of vaginal canal, Stimulates the growth of doderlein bacilli, It is keratolytic, Promotes the peeling of damaged epithelium and Promotes early cervical-vaginal re-epithelialisation. ADVANTAGES: It has $85-95 \% .{ }^{10,11}$ It is simple, safe,effective\& cheap. Alternative to cryo in PHC \& rural hospital. 
II. Materials And Methods :

The study was conducted among 60 patients diagnosed with cervical erosion attending OBG outpatient department ,Adichunchangiri institute of medical sciences ,B.G.nagar over a period of one year. Of these 30 patients were allocated to cryogroup(group A) and 30 patients were allocated to albothyl group(group B). The efficacy of cryo and albothyl solution were measured in terms of time taken for complete healing, number of applications required, associated complications and its success rates.

A detailed history regarding Name, age, sex, socio-economic status, previous STD, organic diseases, allergic to test ingredients, detailed obstetrics and menstrual history was taken. Previous history of OCP's,IUCD insertion \& history and treatment of white discharge was taken and Perspeculum\&Pervaginal examination was done.All patients were counseled and treated on outpatient basis in minor OT.

INCLUSION CRITERIA: 1.Patient with cervical erosion aged between $20 \& 35$ years, No proven or suspected genital tract malignancyWilling for follow-upEXCLUSION CRITERIA: 1.Patient having organic disease , 2.Pregnant women ,3. Who are using local or systemic antibiotics, 4.Patients with abnormal cytology , 5.CIN3, 6 . Large lesions.

In all cases pap smear was taken to rule out abnormal pathology. They were asked to visit after periods for cryo or albothyl solution applications. Patients were followed up $\&$ after $3^{\text {rd }}$ visit pap smear was repeated.

For group A, cervix was swabbed with $3 \%$ acetic acid to dissolve the mucus \& suitable probe was selected for cryounit. 3 minutes freeze, 5minutes thaw, freeze technique (Joule Thompson effect) by using N2O as a refrigerant was used. Freezing was continued till ice-ball was placed 2-3mm beyond the area of erosion for $3 \mathrm{~min}$. Duration, complications \& side-effects were observed $\&$ recorded. Patients were asked to come for follow up at $4^{\text {th }}$ week, $8^{\text {th }}$ week $\& 12^{\text {th }}$ week $\& \mathrm{P} / \mathrm{S}$ examination was done at each visit in $2^{\text {nd }} \& 3^{\text {rd }}$ visit, cryo is repeated for 180-300 seconds if not healed.

For group B, after albothyl application, patients were advised to come for follow up at $7^{\text {th }}$ day, $14^{\text {th }}$ day, $21^{\text {st }}$ day $\& 28^{\text {th }}$ day after initial treatment. During each visit $\mathrm{P} / \mathrm{S}$ was done, symptoms $\&$ signs were assessed. Both the groups received antibiotics for 5 days.

\section{Observation \& Results:}

In our study majority of the women were in the age group between 20 to 30 years, multipara \& $75 \%$ belonged to low socio-economic status. $70 \%$ had low grade infections associated with cervical erosion. Majority of them presented with white discharge per vagina associated with backache.

A. Distribution of cases according to symptoms in both groups A and B :

\begin{tabular}{|l|l|l|}
\hline SYMPTOMS & NO OF CASES & PERCENTAGE \\
\hline White discharge P/V & 30 & $50 \%$ \\
\hline White discharge with backache & 15 & $25 \%$ \\
\hline White discharge with pain abdomen & 10 & $16.5 \%$ \\
\hline White discharge with burning micturition & 5 & $8.3 \%$ \\
\hline
\end{tabular}

B. Distribution of cases according to pre treatmentpap smear report.

\begin{tabular}{|l|l|l|}
\hline PAP SMEAR REPORT & NO OF CASES & PERCENTAGE \\
\hline Inflammatory smear & 45 & $75 \%$ \\
\hline Unsatisfactory & 10 & $16.5 \%$ \\
\hline Normal & 5 & $8.4 \%$ \\
\hline
\end{tabular}

All cases underwent pap smear test and majority of the reports showed inflammatory smear coinciding with cervicovaginal infections

C. Distribution of type of lesions $(A+B)$ :

\begin{tabular}{|l|l|l|}
\hline LESIONS & NO OF CASES & PERCENTAGE \\
\hline Erosion on both the lips & 30 & $50 \%$ \\
\hline Erosion on anterior lip & 10 & $16.5 \%$ \\
\hline Erosion on posterior lip & 15 & $25 \%$ \\
\hline Erosion with nabothian follicle & 5 & $8.4 \%$ \\
\hline
\end{tabular}

Perspeculum examination showed erosion was the commonest lesion. Among them involvement of both lips and posterior lip was more compared to anterior lip. 


\section{Complications during procedure:}

\begin{tabular}{|l|l|l|l|l|}
\hline COMPLICATIONS & GROUP A & & GROUP B \\
\hline & NO OF CASES & PERCENTAGE & NO OF CASES & PERCENTAGE \\
\hline Discomfort with pain & 15 & $50 \%$ & - & - \\
\hline Slight pain & 1 & $3.1 \%$ & - & - \\
\hline No complications & 14 & $47 \%$ & 15 & $50 \%$ \\
\hline Local irritation & - & - & 10 & $33 \%$ \\
\hline Burning sensation & - & - & 5 & $17 \%$ \\
\hline
\end{tabular}

In our study the main complication ws discomfort with slight pain during cryosurgery and local irritation was the main complication in group B patients. Other compliants were minimal such as flushing ,headache, bleeding, burning sensation. Vasovagal attack was nil.

\section{E. Complications after the procedure $(A+B)$ :}

\begin{tabular}{|l|l|l|}
\hline COMPLICATION & NO OF CASES & PERCENTAGE \\
\hline Vaginal discharge & 50 & $83 \%$ \\
\hline Bleeding & 4 & $7 \%$ \\
\hline Post coital bleeding & 2 & $3.1 \%$ \\
\hline Dyspareunia & 2 & $3.1 \%$ \\
\hline Pruritis & 2 & $3.1 \%$ \\
\hline
\end{tabular}

Majority of the patients had vaginal discharge more so in albothyl group and $3 \%$ had discharge of necrotic tissue in group B.

\section{F. Post treated cases with pap smear report :}

\begin{tabular}{|l|l|l|}
\hline PAP SMEAR & NO OF CASES & PERCENTAGE \\
\hline Inflammatory smear & 10 & $16.6 \%$ \\
\hline Normal & 45 & $75 \%$ \\
\hline Unsatisfactory & 5 & $8.3 \%$ \\
\hline
\end{tabular}
normal smear.

Pap smear was taken at the end of $2^{\text {nd }}$ visit in cryo group and $4^{\text {th }}$ visit in Albothyl group. Majority had

\section{G. Interval healing :}

\begin{tabular}{|l|l|l|l|l|l|}
\hline \multicolumn{1}{|c|}{ GROUP A } & & GROUP B & & PERCENTAGE \\
\hline $\begin{array}{l}\text { INTERVAL IN } \\
\text { WEEKS }\end{array}$ & NO OF CASES & PERCENTAGE & $\begin{array}{l}\text { INTERVAL } \\
\text { IN DAYS }\end{array}$ & NO OF CASES & ( \\
\hline 8 & 20 & $66.2 \%$ & 7 & 18 & $60 \%$ \\
\hline 10 & 8 & $26.2 \%$ & 14 & 9 & $30 \%$ \\
\hline 12 & 2 & $6.6 \%$ & 21 & 3 & $10 \%$ \\
\hline
\end{tabular}

In our study healing after cryo was $66 \%$ by 8 weeks and the rest healed by $10-12$ weeks. In group B (Albothylgp) $60 \%$ of cases healed by 1 week and the rest healed by 3 weeks.. $3(3.1 \%)$ cases needed second application.

\section{Discussion:}

Unhealthy cervix comprises a group of lesions like chronic cervicitis, cervical erosion, endocervicitis, polyp lacerations, leucoplakia which can harbor pre-malignant lesions. Hence these conditions when encountered should be evaluated to rule out pre-malignant lesions of the cervix as there is relation between squamous metaplasia \& induction of squamous cell carcionoma, also susceptible to STD infections to species of Chlamydia, N.Gonorrhoea resulting in pelvic pain ${ }^{12}$, post-coital bleeding ${ }^{13}$ and vaginal discharge which is cumbersome. Hence, Leppaluoto ${ }^{14}$ et al was in favour in treating the same and according to Kauraniemi et al it would prevent $15 \%$ incidence of pre-malignant lesions.

\begin{tabular}{|l|l|l|l|l|}
\hline STUDY & $\begin{array}{l}\text { WATERY } \\
\text { DISCHARGE }\end{array}$ & PRURITIS & $\begin{array}{l}\text { SLIGHT } \\
\text { BLEEDING }\end{array}$ & DYSPAREUNIA \\
\hline Our study & $86 \%$ & $5 \%$ & $10 \%$ & $2 \%$ \\
\hline PK Vaidya et al & $89 \%$ & $0.7 \%$ & $36 \%$ & $0.7 \%$ \\
\hline Tounsed et al & $90 \%$ & - & - & - \\
\hline Junnarkar et al & $90 \%$ & - & - & - \\
\hline
\end{tabular}


In our study, $72 \%$ of patients belonged to low socio-economic status and were from rural areas, belonged to reproductive age group between 20-30 years. This study was similar to study by A Mukerjee et al (84\%), PR Vaidya et al (85\%) and Dr.sayedaFiroza Begum(81\%).

Most of the patients presented with white discharge alone or with backache $(72 \%)$. This study was similar to study conducted by Junnarkar et al(90\%), A Mukherjee et al(74\%) and MalathiSholarpurkar et al (97\%). Main complication during the procedure was discomfort with slight pain

$(50 \%)$ and slight bleeding (3.1\%) almost similar to study conducted by A Mukherjee et al where $1 \%$ of the cases had slight bleeding.

$86 \%$ of the cases in our study developed watery discharge after cryo similar to Taunsed et al (90\%), PKVaidya et al (89\%) and Junarkar et al(90.4\%).

Healing of the cervix is achieved completely by metaplasia of mucus membrane to squamous epithelium which occurs in 2-10 weeks ${ }^{15}$. Hence we took pap smear after 12 weeks of therapy. Screening after therapy have shown high success rate of $95 \%$.

\begin{tabular}{|l|l|}
\hline STUDY & GROUP A \\
\hline Our study & $90 \%$ \\
\hline Junnarkar et al (78) & $95 \%$ \\
\hline Khuranna et al (80) & $97 \%$ \\
\hline Ostergard (68) & $90 \%$ \\
\hline & \\
\hline STUDY & GROUP B \\
\hline Our study & $95 \%$ \\
\hline Dr.Ashley Colombo et al & $85 \%$ \\
\hline J Masengi et al & $80 \%$ \\
\hline
\end{tabular}

\section{Conclusion:}

Cervical erosion which occurs in reproductive age group may be forerunner to CIN and later to Carcinoma cervix if unscreened and neglected. Hence thorough evaluation is needed for early detection of precancerous lesions. This can be accomplished in rural population by simple screening procedure as pap smear. Benign lesions respond well to local and systemic antibiotics. Premalignant lesions need ablative therapy and subsequent follow up.

Both cryo and albothyl solution have shown to be simple, safe, effective \& cheap treatment for cervical erosion. Treatment with albothyl solution scores over cryo in being cheaper and cost-effective for rural population and avoids unnecessary surgery and its sequalae

\section{References:}

[1]. Goldacre MJ, Loudon, Wall B et al, epidemiology and clinical significance of cervical erosion in women attending family planning clinic BMJ 1978;1.748-50

[2]. Machado Junior LC, Whitaker DalmasoAS, De Carvalho HB; Evidence for benefits from treating cervical ectopy; literature review saopulo med j 2008;126:132-9.

[3]. Simms, Doltomak D, The cytologic progression from benign to malignant changes in cervical erosion; gynec 1966;162(1); 48-56.

[4]. Sarkar PK, Steel PRM; routine colposcopy prior to treatment of cervical ectopy; is it worthwhile?. Journal Obs gyn,1996:16:96-7

[5]. Dinshaw KA, ShastriSS ; Screening for cervical cancer in India NaH Med J India,2001;14(1):1-3.

[6]. ACOG practice bulletin no99: management of abnormal cervical cytology and histology of gynec 2008,112:1419-1444

[7]. Kashimura M, reparative process of benign erosion of cervix following cryo, gyn, 1980;9:334-350.

[8]. Ashley GS Passenaike-study of the efficacy of albothyl solution in management of vaginitis, cervicitis and cervical erosions, science press publications, 1988

[9]. J Masengi et al study report of the effectiveness of albothyl in cervical erosion 1979.

[10]. Editorial cervical erosion, Brit med Jr 1971(1)456.

[11]. Berek JS, Hillard PA, Nevak, teratodegynecologia 1998.

[12]. Clemetson DB, Moss GB, Willerford DH et al ; detection of HIV DNA in cervical and vaginal secretions, prevalence and correlates among women in Nairobi Kenya:1993;269(22),2860-4

[13]. Leppaluoto P Letter, contraceptive choice and cervical cytology; American journal of Obsgynaecol 1974:118(4):581.

[14]. Young C , Malvera J, Chamberlain ; Outpatient cervical cryotherapy , journal of OBG of british commonwealth, 1972 -1979; $753-5$ 